\title{
Effect of Growth Regulators in Production and Rooting of Coffea arabica L. Minicuttings
}

\author{
Paulo Fernando Marques Cavalcanti Filho, Diego Corona Baitelle, Sílvio de Jesus Freitas, \\ Waldinei Souza da Silva, Paulo Cesar dos Santos, Weverton Pereira Rodrigues, \\ Silvério de Paiva Freitas, Ismael Lourenço de Jesus Freitas, Tamara Locatelli, \\ Abraão Carlos Verdin Filho, Guilherme Bessa Miranda \\ Department of Plant Science, State University of Northern Rio de Janeiro, Campos dos Goitacazes, Rio de Janeiro State, Brazil \\ Email:paulo_fmcf@hotmail.com,dg.corona@gmail.com,freitassj@yahoo.com.br, silveriopfreitas@gmail.com, \\ waldineisouza33@gmail.com,pcsantos18@hotmail.com,ismaelmjf@yahoo.com.br, \\ tamaralocatelli@gmail.com,verdin.abcfilho@gmail.com,gbm3009@hotmail.com
}

How to cite this paper: Cavalcanti Filho, P.F.M., Baitelle, D.C., Freitas, S. de J., da Silva, W.S., dos Santos, P.C., Rodrigues, W.P., Freitas, S. de P., de Jesus Freitas, I.L., Locatelli, T., Verdin Filho, A.C. and Miranda, G.B. (2018) Effect of Growth Regulators in Production and Rooting of Coffea arabica L. Minicuttings. American Journal of Plant Sciences, 9, 628-636.

https://doi.org/10.4236/ajps.2018.94049

Received: November 9, 2017

Accepted: March 9, 2018

Published: March 12, 2018

Copyright ( 92018 by authors and Scientific Research Publishing Inc. This work is licensed under the Creative Commons Attribution International License (CC BY 4.0).

http://creativecommons.org/licenses/by/4.0/

(c) (i) Open Access

\begin{abstract}
The plants of $C$. arabica do not naturally produce a large number of orthotropic sprouts, hindering clonal multiplication by cutting, which would be the simplest technique with a lower cost of production compared to other methods of vegetative propagation. An alternative form, used successfully in the propagation of eucalyptus, is propagation by minicutting, which consists of pruning the shoot apex of the plant, forming the ministumps, which in variable time interval emits the shoots that will be used to make minicutting. In $C$. arabica plants the number of shoots can be increased with the application of growth regulators and fertilizers. So, the purpose of this work was to verify the effect of growth regulators and foliar fertilizers on the emission and development of orthotropic shoots of $C$. arabica. The experiment was installed in a randomized complete block design, with ten treatments composed by growth regulators and fertilizers: T1 (Control); T2 (Stimulate + Sturdy + Enervig); T3 (Stimulate + Vitakelp + Biozyme); T4 (Tiba + Sturdy + Enervig); T5 (Tiba + Vitakelp + Biozyme); T6 (Brs + Sturdy + Enervig) T7 (Brs + Vitakelp + Biozyme); T8 (Stimulate); T9 (TIBA); T10 (Brs-Brassinoesteroid), each plot consisting of two plants. Biometric and physiological parameters were evaluated for the ministumps, as well as the biometric parameters of the shoots and plant survival. The results showed that there was no influence of the treatments on the biometric parameters of the ministumps. A greater number of orthotopic sprouts were obtained in treatments with the TIBA growth regulator, as well as a greater plant survival of the minicuttings, after 25 days of transplanting in a greenhouse. It was concluded that TIBA treatments influenced the production and quality of clonal minicuttings of $C$. arabica.
\end{abstract}




\section{Keywords}

Arabica Coffee, Ministumps, Clonal Propagation

\section{Introduction}

The production of quality seedlings is the first step in the process of forming a good quality coffee. $C$. arabica cultivars are propagated sexually and due to their morphological characteristics, they undergo a very long process of material selection, usually requiring more than 25 years for the characteristics of interest of the cultivars to be stabilized [1].

The vegetative propagation of $C$. arabica is justified for the immediate exploration of $\mathrm{F} 1$ hybrids, representing a great saving of time by reducing the number of selection cycles to obtain lineages, guaranteeing the uniformity of the population and maintenance of the genetic gain obtained in the selection [2] [3] [4].

The clonal propagation by cutting, traditionally used in the C. canephora, did not succeed in the clonal propagation of $C$. arabica. Although no anatomical barriers are found for the rooting of $C$. arabica cuttings from orthotropic sprouts [3], and they have good rooting [2], coffee plants of the arabica species do not naturally produce a large number of orthotropic sprouts, making multiplication difficult by cutting.

Other authors [5] observed a very variable production of orthotropic sprouts in C. arabica genotypes cloned in vitro, being these limiting characteristics in the clonal propagation of the species in commercial scale, mainly by cutting, since it would require a large area for the formation of registered nurseries, which would directly influence the final cost of the seedlings.

An alternative form of clonal propagation is propagation by minicutting. In this technique, minicuttings are taken from ministumps in clonal mini-clonal hedges, usually established inside greenhouse [6]. This technique is based on the higher juvenility of minicuttings obtained from shoots in successive collections in this system, thus providing better rooting indices of plant material [7].

The benefits of mini-clonal hedges range from reduced space, greater control of plant health, and environmental control, which may influence the adhesion of seedlings from cuttings, as the field plants suffer from climate conditions, among other factors controlled in the nurseries at propagation by minicutting [8].

The number of orthotropic shoots in coffee plants can be increased with the application of growth regulators. TIBA (2,3,5-triiodobenzoic) is an inhibitor of polar auxin transport, acting directly on the apical dominance of the plant [9]. In this work was observed [1] that TIBA influenced the number of shoots in C. arabica seedlings in mini-clonal hedges.

The brassinosteroids (BRs) are polyhydroxy steroidal lactones that occur naturally in plants, influence various developmental processes, such as germination and seed vigor, flowering and dormancy of buds and seeds in certain crops [10] 
[11].

Stimulate ${ }^{\circledast}$ is a commercial product of Stoller do Brasil Ltda., Containing plant regulators and traces of chelated mineral salts. Its constituent plant regulators are indolebutyric acid (auxin) $0.005 \%$, kinetin (cytokinin) $0.009 \%$ and gibberellic acid (gibberellin) $0.005 \%$. This product reveals that it is able to assist in breaking dormancy of the lateral buds in some cultures [12] [13].

The nutritional status of ministumps and shoots in vegetative propagation by minicuttings has been pointed out as one of the main factors in adventitious rooting of minicuttings, but few studies have been conducted aiming at the characterization of the effects of specific nutrients [14] [15].

The objective of this work was to evaluate the influence of growth regulators and foliar fertilizers on sprouting and rooting of minicuttings of $C$. arabica.

\section{Material and Methods}

The experiment was conducted at the State University of Northern Fluminense Darcy Ribeiro-UENF, in the municipality of Campos dos Goytacazes-RJ, located at $21^{\circ} 48^{\prime}$ latitude, $41^{\circ} 20^{\prime}$ long at an altitude of $11 \mathrm{~m}$. The average annual temperature is $24^{\circ} \mathrm{C}$, with average annual precipitation of $1023 \mathrm{~mm}$.

The experimental design was a randomized block with 10 treatments, with 4 blocks with 2 plants per block, totaling 80 experimental units. The treatments were elaborated from the combination of growth regulators and commercial fertilizers: T1 (Control); T2 (Stimulate + Sturdy + Enervig); T3 (Stimulate + Vitakelp + Byozime); T4 (Tiba + Sturdy + Enervig); T5 (Tiba + Vitakelp + Byozime); T6 (Brs + Sturdy + Enervig); T7 (Brs + Vitakelp + Byozime); T8 (Stimulate); T9 (TIBA); T10 (Brassinosteroid).

The foliar fertilizers used had the following compositions: Sturdy: (Nitrogen [N] 86.4 g/L; Phosphorus $\left[\mathrm{P}_{2} \mathrm{O}_{5}\right] 432.0$ g/l; Complexing agent-MEA 20\%; Biozyme TF: Nitrogen [N] 20.7 g/l, Potassium [K20] 60 g/l, Boron [B] 0.96 g/l, Iron [Fe] $5.9 \mathrm{~g} / \mathrm{l}$, Manganese [Mn] $12 \mathrm{~g} / \mathrm{l}$, Sulfur [S] $25.2 \mathrm{~g} / \mathrm{l}$, Zinc [Zn] $29.1 \mathrm{~g} / \mathrm{l}$, Total organic carbon $42.0 \mathrm{~g} / \mathrm{l}$ ); Enervig: (Copper [Cu] $17.02 \mathrm{~g} / \mathrm{l}$, Manganese [Mn] 17.02 g/l, Iron [Fe] 22.02 g/l, Zinc [Zn] 33.92 g/l); Vitakelp: (Nitrogen [N] 180.0 g/l; Potassium [K20] 12.0 g/l; Algae Extract and Amino Acids).

Seedlings from the "Catuaí Vermelho IAC 99" were used to make the ministumps in cylindrical vases of $17 \times 22 \times 16 \mathrm{~cm}$. The substrate used to fill the pots was Basaplant. Irrigation and cultural treatments were performed according to the recommendations of [16].

The apical meristem of the seedlings broke after the six months of age, and the height of the seedlings was standardized in $15 \mathrm{~cm}$. Growth regulators and foliar fertilizers were applied 10 days after the apical meristem was broken and ministumps, and the treatments were repeated every 30 days.

The following variables were evaluated biometric: number of leaves; height of the plants; diameter of the neck; weight of dry matter of the aerial part and weight of dry matter of the roots, measured in digital analytical balance, after the 
material was dried in an oven at $70^{\circ} \mathrm{C}$ for 72 hours. The root system was evaluated for volume, length and root diameter determined after root scanning and subsequent analysis of the images in the WinRHIZO program. The leaf green color intensity was also measured using a Portable Chlorophyll Meter SPAD-502 "Soil Plant Analyzer Development" (Minolta, Japan), where three readings were taken along the plant and the average was used to compose each repetition.

The number of shoots was measured; number of shoots leaves; length of shoots, measured from the base of the orthotropic branch to the apex of the branch; diameter of the shoots; dry matter weight of the shoots after the material was dried under study at $70^{\circ} \mathrm{C}$ for 72 hours and fresh matter weight of the shoots measured in analytical digital scale.

The data of the index of glue were evaluated according to the methodology applied by [17], the Index of Pickle Glue (IPG), relates the number of pegs taken per plot, with the number of cuttings planted per plot, according to the formula:

$$
\text { IPG }(\%)=\frac{\text { Number of pickets per plot } \times 100}{\text { Number of cuttings planted per plot }}
$$

The data collected were submitted to analysis of variance, in which the means of the treatments were studied by the Tukey test $(\mathrm{p}<0.05)$.

\section{Results and Discussion}

According to the analysis of variance of the biometric and physiological of the ministumps, for each of the parameters evaluated are shown in Table 1. It is observed that there was no significant difference between the means of the treatments for all the biometric parameters and physiological variables evaluated in the ministumps.

Table 1. Summary of the analysis of variance for the parameters evaluated in the matrices: Fresh weight, Initial leaf number, SPAD index, Initial height, Initial diameter, Dry weight, Final diameter, Final height and Final number of leaves.

\begin{tabular}{ccccc}
\hline \multicolumn{5}{c}{ F values } \\
\hline Variation source & $\begin{array}{c}\text { Fresh weight } \\
(\mathrm{g})\end{array}$ & $\begin{array}{c}\text { Initial number } \\
\text { of leaves }\end{array}$ & SPAD & $\begin{array}{c}\text { Initial diameter } \\
(\mathrm{cm})\end{array}$ \\
\hline Treatments $^{1}$ & $1.441^{\mathrm{ns}}$ & $0.7258^{\mathrm{ns}}$ & $0.3583^{\mathrm{ns}}$ & $0.4106^{\mathrm{ns}}$ \\
Overall Average & 6.7322 & 9.7625 & 44.8362 & 2.8430 \\
CV (\%) & $29.078 \%$ & $14.892 \%$ & $9.706 \%$ & $12.175 \%$ \\
\hline Variation source & Dry Weight & Final Diameter & Final Height \\
$(\mathrm{g})$ & $(\mathrm{cm})$ & Final number of \\
Treatments & & $1.6742^{\mathrm{ns}}$ & $1.8749^{\mathrm{ns}}$ & leaves \\
\hline Overall Average & 2.4355 & 2.297 & 12.610 & $0.5922^{\mathrm{ns}}$ \\
CV (\%) & $21.401 \%$ & $18.049 \%$ & $10.083 \%$ & 9.4125 \\
& & & & $13.715 \%$
\end{tabular}

${ }^{*}$ significant at the level of $1 \%$ of probability by the F test; ${ }^{*}$ significant at the level of $5 \%$ of probability by the F test; ${ }^{\text {ns }}$ not significant $(\mathrm{p}>0.05)$ by the F test. 
The time elapsed between the application of growth regulators and foliar fertilizers and the final evaluation of the experiment was 90 days. This period was probably short for growth regulators and fertilizers to induce a significant effect on the biometrics of the plants analyzed. Another factor that may have contributed to these results is the quality of the seedlings used, since they were acquired in a certified nursery and had good visual characteristics (size and color of the appropriate leaves and sprouts).

In Table 2 was observed the summary of the analysis of variance of the data collected from the roots of the ministumps through the program WinRHIZO, with the determined values of $\mathrm{F}$. It is observed that there was no significant difference between the means of the treatments for all the parameters evaluated in the roots of the ministumps.

According to the results obtained in Table 3, which evaluated the production of minicuttings, it was observed that there was a significant difference between the treatments in relation to the number of shoots of the ministumps, length of shoots, diameter of shoots.

In relation to the number of shoots, the treatments (T5, T4 and T9) that received the TIBA growth regulator showed higher sprouting averages, the other treatments did not differ among themselves, being statistically similar to the T1

Table 2. Summary of the analysis of variance for the parameters evaluated in the roots of the ministumps by the program WinRHIZO: Root length, Surface area, Root volume, Root density.

\begin{tabular}{ccccc}
\hline \multicolumn{5}{c}{ F Values } \\
\hline Variation source & $\begin{array}{c}\text { Variation Root } \\
\text { length }(\mathrm{cm})\end{array}$ & $\begin{array}{c}\text { Surface area } \\
\left(\mathrm{cm}^{2}\right)\end{array}$ & $\begin{array}{c}\text { Root volume } \\
\left(\mathrm{cm}^{3}\right)\end{array}$ & $\begin{array}{c}\text { Root density } \\
\left(\mathrm{g} / \mathrm{cm}^{3}\right)\end{array}$ \\
\hline Treatments & $1.9916^{\mathrm{ns}}$ & $1.0295^{\mathrm{ns}}$ & $1.5074^{\mathrm{ns}}$ & $1.1873^{\mathrm{ns}}$ \\
Overall Average & 136.0237 & 13.39075 & 1.2322 & 11.4445 \\
CV (\%) & $17.111 \%$ & $9.223 \%$ & $23.361 \%$ & $23.641 \%$ \\
\hline
\end{tabular}

${ }^{*}$ Significant at the level of $1 \%$ of probability by the $\mathrm{F}$ test; ${ }^{*}$ significant at the level of $5 \%$ of probability by the F test; ${ }^{\text {ns }}$ not significant $(\mathrm{p}>0.05)$ by the $\mathrm{F}$ test.

Table 3. Summary of the analysis of variance for the parameters evaluated in the shoots: Diameter of shoots, Length of shoots, Number of shoots, Fresh weight of shoots and Dry weight of shoots.

\begin{tabular}{cccccc}
\hline \multicolumn{1}{c}{ F Values } \\
\hline $\begin{array}{c}\text { Variation } \\
\text { source }\end{array}$ & $\begin{array}{c}\text { Diameter of } \\
\text { shoots }(\mathrm{cm})\end{array}$ & $\begin{array}{c}\text { Length of } \\
\text { shoots }(\mathrm{cm})\end{array}$ & $\begin{array}{c}\text { Number of } \\
\text { shoots }\end{array}$ & $\begin{array}{c}\text { Fresh weight } \\
\text { of shoots }(\mathrm{g})\end{array}$ & $\begin{array}{c}\text { Dry weight } \\
\text { of shoots } \\
(\mathrm{g})\end{array}$ \\
\hline $\begin{array}{c}\text { Treatments } \\
\text { Overall }\end{array}$ & $3.7730^{* *}$ & $2.8354^{* *}$ & $13.1148^{* *}$ & $0.8427^{\text {ns }}$ & $0.3722^{\text {ns }}$ \\
Average & 2.3772 & 1.3992 & 5.400 & 2.895 & 0.8220 \\
CV (\%) & $10.588 \%$ & $31.961 \%$ & $28.130 \%$ & $44.112 \%$ & $37.651 \%$ \\
\hline
\end{tabular}

${ }^{*}$ Significant at the level of $1 \%$ of probability by the $\mathrm{F}$ test; ${ }^{*}$ significant at the level of $5 \%$ of probability by the F test; ${ }^{\text {ns }}$ not significant $(\mathrm{p}>0.05)$ by the F test. 
(control). These results corroborate with the data obtained by [1], who also observed that there is an increase in the number of orthotropic buds formed by a year-old $C$. arabica plant sprayed with TIBA in a clonal garden (Figure 1).

The application of brassinosteroids did not prove to be efficient in the formation of shoots in coffee plants. These results corroborate with those found by [18] that verified that the brassinosteroids did not interfere in the breakage of dormancy of the lateral buds and in the growth of the apple tree sprouts. However, the results differ from those obtained by [12] where the brassinosteroids provided positive effects on the development of axillary buds of sections of the pineapple.

It was observed that T1 (control) presented a higher average length of shoots compared to treatments T2, T4, T5, T7 and T8, but did not differ from other treatments. It can be verified that the length of the shoots can be related to the number of shoots per ministumps, since, the witness had a lower number of shoots, but a longer length of shoots, and the treatments T5 and T4, which presented higher averages as to the number of shoots significantly lower mean values than the control group (Figure 2).

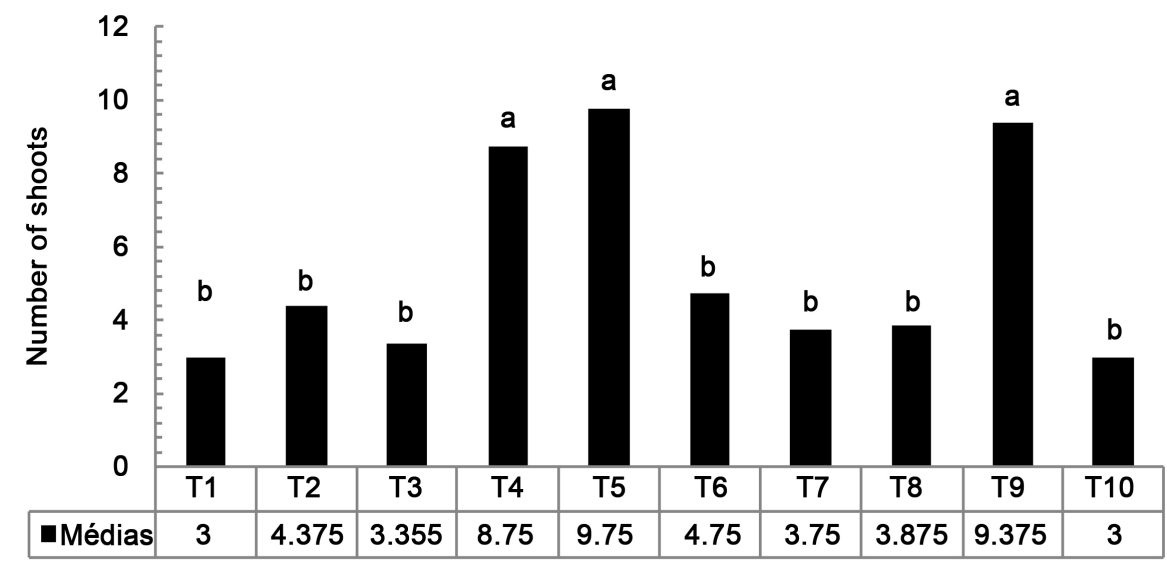

Figure 1. Total mean number of shoots at the end of the experiment. Evaluated by Tukey test with $5 \%$ probability.

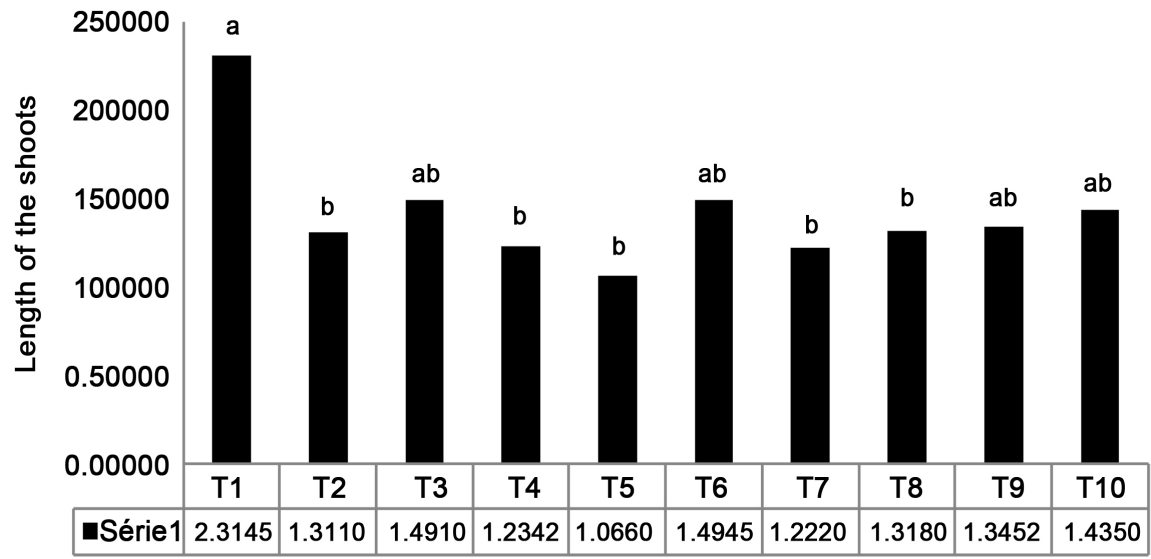

Figure 2. Mean length of the shoots. All evaluated by Tukey test with 5\% probability. 
It is verified that T10 had higher shoot size averages when compared to T4 and $\mathrm{T} 5$, not differing from the other treatments. This result may be associated to the lower number of shoots obtained in treatment 10 , which in relation to $\mathrm{T} 4$ and T5 were respectively $291 \%$ and $325 \%$ lower, another possibility is that the brassinosteroids has influenced the development of shoot diameter, corroborating with results obtained by [12] who verified that the brassinosteroids provided an increase in the diameter of pineapple seedlings (Figure 3 ).

Figure 4 shows the result of the glue index of the minicuttings collected. It can be verified that the minicuttings from the T5 and T4 treatments obtained, respectively, a higher glue index of the minicuttings. The results of $37.5 \%$ and $25 \%$ can be considered satisfactory, since the time of rooting was only 25 days, being necessary time of rooting for minicuttings, not being conclusive. According to [19], the $C$. arabica species needs to remain in the nebulization house for about 90 days in order to obtain satisfactory rooting results.

\section{Conclusions}

According to the data obtained in the experiment, we conclude that:

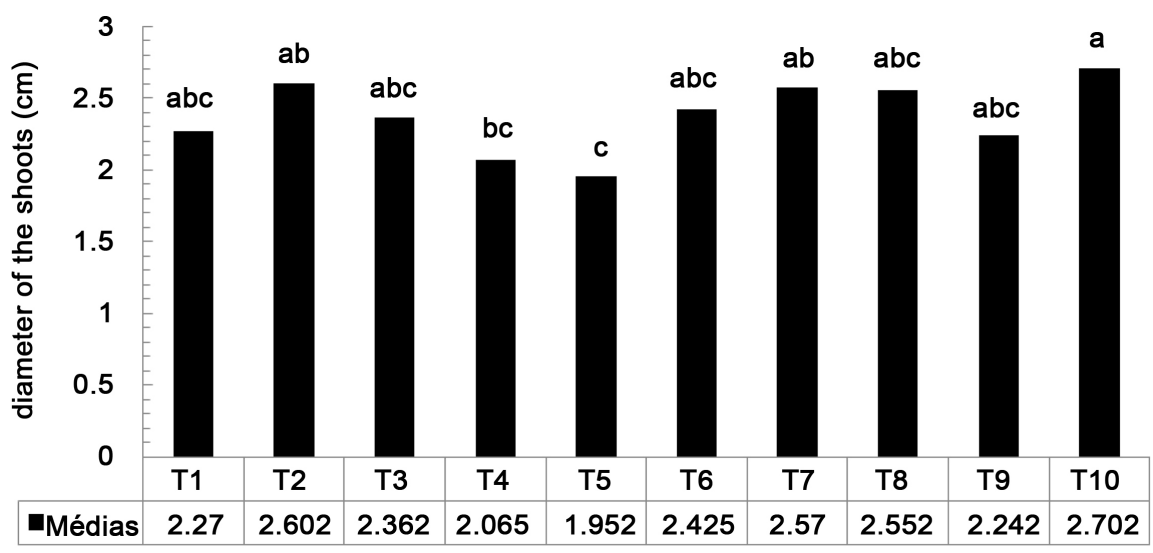

Figure 3. Average diameter of the shoots. All evaluated by Tukey test with $5 \%$ probability.

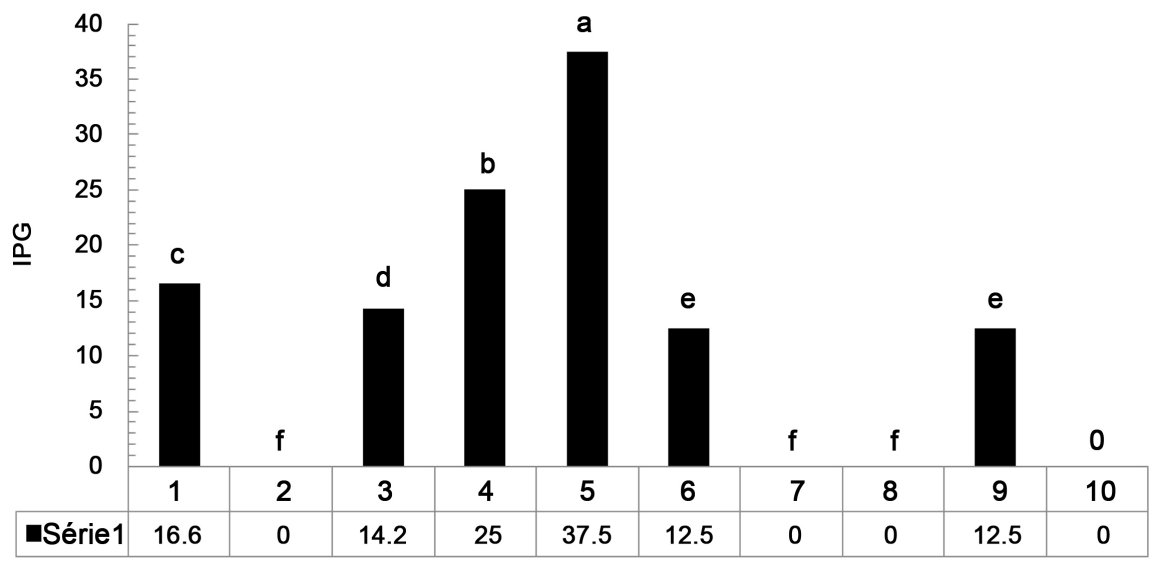

Figure 4. Tukey's test at 5\% of significance for the parameter of Index Picket Glue for the quantification of $C$. arabica minicuttings with 25 days of nebulization transfer. 
1) The production of minicuttings from axillary buds of arabica coffee is possible, since both orthotropic shoot production and rooting were obtained.

2) The TIBA growth regulator positively influences the production of minicuttings of arabica coffee.

3) The technique of seedlings production in mini-clonal hedges can be an interesting technological innovation, since it can be used to reduce the generation time, and the possible exploitation of F1 descendants.

\section{References}

[1] de Carvalho, C.H.S., Oliveira, P.L.D., Santos, A.C.R., Fagundes, A.V. and Souza, T. (2007) Efeito de reguladores de crescimento sobre a produção de brotos ortotrópicos axilares em mudas de café. In Embrapa Café-Artigo em anais de congresso (ALICE). Simpósio de Pesquisa dos Cafés do Brasil, Águas de Lindóia, Embrapa Café, Brasília, DF.

[2] Pereira, A.B. (2000) Enraizamento de estacas de Coffea arabica L. Tese Doutorado. Universidade Federal de Lavras, Lavras, $75 f$.

[3] Jesus, A.M.S., de Carvalho, S.P., de Castro, E.M. and Gomes, C.N. (2015) Observações anatômicas em plantas de Coffea arabica L. obtidas por enraizamento de estacas. Ceres, 57, 175-180. https://doi.org/10.1590/S0034-737X2010000200006

[4] Mesén, F. and Jiménez, L.D. (2016) Producción de clones de café por miniestacas.

[5] Bueno, I.F., Carli, J.R.D., Fernandes, B., Angelo, P.C.D.S. and Carvalho, C.H.S.D. (2015) Avaliação da produção de ramos ortotrópicos em genótipos de cafeeiro catucaí amarelo e siriema clonados in vitro. Simpósio de Pesquisa dos Cafés do Brasil, EMBRAPA Café, Curitiba. http://www.sbicafe.ufv.br/handle/123456789/3597

[6] Xavier, A., Santos, G.A.D. and Wendling, I. (2003) Propagação vegetativa de cedro-rosa por miniestaquia. Revista Árvore, Viçosa, MG, 27, 139-143. https://doi.org/10.1590/S0100-67622003000200003

[7] Alfenas, A.C. and Mafia, R.G. (2007) Hibridação e clonagem. In: Borém, A., Ed., Biotecnologia Florestal, Suprema, Viçosa, 93-121.

[8] Titon, M. (2001) Propagação clonal de Eucalyptus grandis por miniestaquia e microestaquia. 65f. Dissertação (Mestrado em Ciência Florestal), Universidade Federal de Viçosa, Viçosa.

[9] Rehm, S., Espig and Zayed, E.A. (1978) Stimulation of Sprouting of Secondary Buds on Coffee Seedlings by Growth Regulators. Plant Research and Development, 7, 96-107.

[10] Freitas, S.D.J., Santos, P.C., Da Silva Berilli, S., Lopes, L.C. and De Carvalho, A.J.C. (2014) Brotação, desenvolvimento e composição nutricional de mudas de abacaxizeiro provenientes de gemas axilares submetidas ao brassinosteroide. Revista Brasileira de Ciências Agrárias (Agrária) Brazilian Journal of Agricultural Sciences, 9, 19-24. https://doi.org/10.5039/agraria.v9i1a3270

[11] Clouse, S.D. (2002) Brassinosteroids Plant Counterparts to Animal Steroid Hormones? Vitamins \& Hormones, 65, 195-223. https://doi.org/10.1016/S0083-6729(02)65065-4

[12] Camili, E.C., Rodrigues, J.D. and Ono, E.O. (2010) Biorreguladores na brotação da videira 'superior seedless'. Bioscience Journal, 26, 339-346.

[13] Botelho, R.V. (2008) Uso de biostimulante para a quebra de dormência de macieira cv. Castel gala. Scientia Agraria, 9, 399-403. https://doi.org/10.5380/rsa.v9i3.11706 
[14] Schwambach, J., Fadanelli, C. and Fett-Neto, A.G. (2005) Nutrição mineral e enraizamento adventicioso em microcortes de Eucalyptus globulus. Tree Physiology, Victoria, 25, 487-494. https://doi.org/10.1093/treephys/25.4.487

[15] Cunha, A.C.M.C.M.D., Paiva, H.N.D., Leite, H.G., Barros, N.F.D. and Leite, F.P. (2009) Influência do estado nutricional de minicepas no enraizamento de miniestacas de eucalipto.

[16] Matiello, J.B., Santiago, R., Almeida, S.R. and Garcia, A.W.R. (2015) Cultura de café no Brasil: Manual de recomendações. Futurama Editora, São Paulo, 585 p.

[17] Costa, B.M., da Capinan, G.C.S., Dos Santos, H.H.M. and Alves Dasilva, M. (2004) Métodos de plantio de gliricídia (Gliricidia sepium (Jacq.) Walp.) em estacas para produção de forragem. Revista Brasileira de Zootecnia, 33, 1969-1974. https://doi.org/10.1590/S1516-35982004000800007

[18] Hilgenberg, T. and Ayub, R.A. (2014) Avaliação de Brassinosteróides na quebra de dormência e no crescimento de ramos de Macieira (Malus domestica). [Evaluation of Brassinosteroids in Dormancy Break and in Growth of Branches of Apple Tree (Malus domestica).] Ambiência, 10, 625-630.

[19] Fadelli, S., Sera, T., Azevedo, J.A.D., Alteia, M.Z., Colombo, L.A., Mata, J. and Fadelli, S. (2000) Estaquia de cafeeiros arábicos de diferentes genotipos: Tipo de estaca. SIMPOSIO de Pesquisa dos Cafés do Brasil, 1, Pocos de Caldas (Brasil), 26-29 Setembro 2000, Resumos expandidos. 